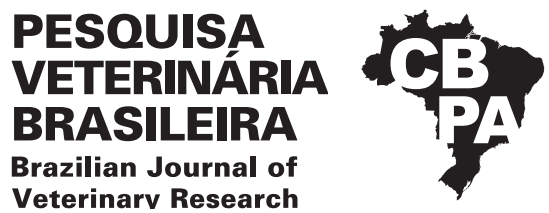

Pesq. Vet. Bras. 41:e06880, 2021

DOI: $10.1590 / 1678-5150-P V B-6880$

Original Article

Veterinarv Research

ISSN 0100-736X (Print)

Livestock Diseases

ISSN 1678-5150 (Online)

\title{
Evaluation of interferon-stimulated gene 15 (ISG15) expression in blood neutrophils in beef cattle poisoned by Senecio spp. ${ }^{1}$
}

\author{
Simone Stefanello ${ }^{2}$, Carolina S. Amaral ${ }^{2}$, Igor G. Zappe², Lady K.S. Mujica², \\ Mauren P. Emanuelli ${ }^{3}$, Valério M. Portela ${ }^{2}$, Adriano T. Ramos ${ }^{4}$ \\ and Alfredo Q. Antoniazzi ${ }^{2 *}$ (D)
}

\begin{abstract}
Stefanello S., Amaral C.S., Zappe I.G., Mujica L.K.S., Emanuelli M.P., Portela V.M., Ramos A.T. \& Antoniazzi A.Q. 2021. Evaluation of interferon-stimulated gene 15 (ISG15) expression in blood neutrophils in beef cattle poisoned by Senecio spp. Pesquisa Veterinária Brasileira 41:e06880, 2021. Laboratório de Biotecnologia e Reprodução Animal, Universidade Federal de Santa Maria, Av. Roraima 1000, Santa Maria, RS 97105-900, Brazil. E-mail: alfredo.antoniazzi@ufsm.br

This study aimed to assess liver damage and interferon-stimulated gene 15 (ISG15) blood expression as a consequence of embryonic signaling on maternal recognition of pregnancy in beef cattle presenting natural ingestion of Senecio spp. Epidemiological aspects, as the presence of the plant, associated to gamma glutamyl transferase (GGT) activity can be used as Senecio spp. poisoning diagnosis. Maternal recognition of pregnancy period occurs when the embryo secretes interferon tau (IFNT) to signal its presence to the mother and eventually extend corpus luteum (CL) lifespan. In our study, liver damage was determined by concentration serum GGT, cytological and histopathological examinations. Reproductive status was evaluated by concentration of progesterone, CL diameter and ISG15 mRNA expression on Day 19 following fixed-time artificial insemination (FTAI). Cows were categorized into two groups based on concentration of GGT: Group 1 (GGT<30U/L) and 2 (GGT>31U/L). No difference on body condition scores was observed. All the cows presented liver damage based on cytology and histopathological exams. Cows from the Group 1 had higher pregnancy rate, presenting larger CL diameter and greater concentration of progesterone. Interestingly, ISG15 mRNA expression had no difference between Groups 1 and 2, even presenting difference in pregnancy status. These findings suggest embryonic loss beyond Day 19. It suggests late embryonic mortality may be associated to liver insufficiency. In conclusion, liver injury and/or concentration of GGT does not alter ISG15 expression on blood neutrophils, however cows presenting lower concentration of GGT $(<30 \mathrm{U} / \mathrm{L})$ had increased pregnancy status. Therefore, the concentration of GGT allow us to screen liver status and foresee a successful pregnancy in beef cattle.
\end{abstract}

INDEX TERMS: Interferon, gene, ISG15, blood neutrophils, beef cattle, toxic plants, Senecio spp., embryo, GGT, liver, pregnancy, progesterone, seneciosis.

RESUMO.- [Avaliação da expressão do gene estimulado por interferon 15 (ISG15) em neutrófilos sanguíneos em bovinos de corte intoxicados por Senecio spp.] 0 objetivo

\footnotetext{
${ }^{1}$ Received on January 26, 2021.

Accepted for publication on April 9, 2021.

${ }^{2}$ Laboratório de Biotecnologia e Reprodução Animal, Universidade Federal de Santa Maria (UFSM), Av. Roraima 1000, Santa Maria, RS 97105-900, Brazil. *Corresponding author: alfredo.antoniazzi@ufsm.br

${ }^{3}$ Universidade Federal do Pampa (Unipampa), Campus Uruguaiana, BR$472 \mathrm{Km}$ 585, Uruguaiana, RS 97501-970, Brazil.

${ }^{4}$ Universidade Federal de Santa Catarina (UFSC), Campus Curitibanos, Rodovia Ulysses Gaboardi 3000, Curitibanos, SC 89520-000, Brazil.
}

deste estudo foi avaliar a lesão hepática e a expressão sanguínea do gene estimulado por interferon 15 (ISG15) durante a sinalização embrionária, no reconhecimento materno da gestação, em bovinos de corte apresentando ingestão natural de Senecio spp. Fatores epidemiológicos, como a presença da planta, associados à atividade da gama glutamil transferase (GGT) podem ser utilizados como diagnóstico da intoxicação por Senecio spp. 0 reconhecimento materno da gestação ocorre quando o embrião secreta interferon tau (IFNT) para sinalizar sua presença à mãe. Em nosso estudo, a lesão hepática foi determinada pela concentração sérica de GGT, pelos exames citológicos e histopatológicos. 0 estado reprodutivo foi avaliado 
pela concentração de progesterona, diâmetro de corpo lúteo (CL) e expressão de mRNA ISG15 no Dia 19 após a inseminação artificial em tempo fixo (IATF). As vacas foram separadas em dois grupos com base na concentração de GGT sanguíneo: Grupo 1 (GGT<30U/L) e Grupo 2 (GGT>31U/L). Não foi observada nenhuma diferença no escore de condição corporal entre os grupos. Na citologia e nos exames histopatológicos todas as vacas apresentaram lesão hepática. As vacas do Grupo 1 apresentaram maior taxa de prenhez, maior diâmetro do CL e maior concentração de progesterona. Diferente do esperado, a expressão do mRNA ISG15 não foi diferente entre os Grupos 1 e 2, mesmo apresentando diferença na taxa de prenhez. Esses achados sugerem perda embrionária após o Ddia 19. Isso demonstra que a mortalidade embrionária tardia pode estar associada à insuficiência hepática. Dessa forma, conclui-se que a lesão hepática e/ou concentração de GGT não altera a expressão de ISG15 nos neutrófilos sanguíneos, porém vacas com menor concentração de GGT (<30U/L) apresentaram maiores taxas de prenhez. Assim, a concentração de GGT nos permite avaliar a saúde hepática e prever uma gestação bemsucedida em bovinos de corte.

TERMOS DE INDEXAÇÃO: Interferon, ISG15, neutrófilos, bovinos de corte, plantas tóxicas, Senecio spp., embrião, fígado, gestação, GGT, progesterona, seneciose.

\section{INTRODUCTION}

The poisoning by Senecio spp. plant is the major cause of death in cattle in Southern Brazil (Giaretta et al. 2014). Senecio spp. is a genus of native plants to various regions of the world and are considered to cause an enzootic disease in cattle (Basile et al. 2005). Pyrrolizidine alkaloids (PA) are natural phytotoxins (Elias et al. 2011) that constitute the genus Senecio spp. and cause irreversible liver damage (Barros et al. 2007). The toxicity causes structural and functional changes in hepatocytes (Santos et al. 2008) impairing liver function (Cheeke 1988). Considering the effects of poisoning by Senecio spp. in reproductive tissues, there is one study reporting a sporadic effect on cells expressing P-450 cytochrome, such as large steroidogenic cells in the corpus luteum (CL) (Krabbe et al. 2015). Seneciosis diagnosis is determined by the presence of the plant, epidemiological aspects and assessment of liver function (Karam et al. 2004), characterized by megalocytosis, fibrosis, and hyperplasia of biliary ducts on histopathological exam as the gold standard (Barros et al. 2007), but also cytological exam can be used (Emanuelli et al. 2016). Another additional approach is the biochemical diagnosis of Senecio spp. poisoning in cattle using serum gamma glutamyl transferase (GGT), a hepatic enzyme originating from the membranes of the bile ducts and canaliculi (Santos et al. 2008).

One of the main causes of reproductive failure in cattle is early embryonic mortality, especially during the first 30 days of pregnancy (Wiltbank et al. 2016). After ovulation and subsequent CL formation, blastocyst growth and fetal elongation are in part dependent on the concentration of progesterone (Spencer et al. 2006). Serum concentration of progesterone is determined by the balance between its production and hepatic metabolism (Wiltbank et al. 2014). Additionally, the adequate endometrial environment necessary for embryo development is positively influenced by progesterone concentration, increasing factors enabling the conceptus growth and survival (Spencer et al. 2016).

In order to recognize and maintain the pregnancy, the concept needs to signal its presence to the mother (Spencer \& Bazer 2004) through the maximum production of interferon tau (IFNT) (Imakawa et al. 1987), which promotes maternal adequate progesterone secretion needed for the establishment of pregnancy (Farin et al. 1989). Besides IFNT mechanism on maternal recognition of pregnancy (Spencer \& Bazer 1996), it also increases the expression of various interferonstimulated genes (ISGs), such as interferon-stimulated gene 15 (ISG15) in the uterus (Austin et al. 1996), corpus luteum (CL) (Oliveira et al. 2007), liver (Bott et al. 2010) and leukocytes (Han et al. 2006). In the CL specifically, IFNT stimulates the expression of anti-apoptotic genes (Antoniazzi et al. 2013), as a consequence of endocrine action of IFNT (Oliveira et al. 2007). Early pregnancy diagnosis has also been suggested through the differential expressions of ISGs mRNAs in peripheral blood cells during early embryonic development (Kizaki et al. 2013). The analysis of gene expression in separate fractions of peripheral blood leucocytes (PBL), especially the polymorphonuclear cells (PMN) fraction are most sensitive to IFNT stimulation than the mononuclear cells (PBMC) fraction (Haq et al. 2016, Toji et al. 2017), presenting a great correlation between ISGs expression and early pregnancy in bovines (Kizaki et al. 2013). However, some studies have proposed the expression of ISGs in neutrophils could be peripheral markers to predict embryonic mortality (Sheikh et al. 2018).

Considering the liver damage in cows by seneciosis, the cholesterol and progesterone metabolism and urea synthesis may be altered, and indirectly influence embryo elongation and signaling to the mother. Hence, our hypothesis is that pregnant beef cows presenting chronic liver injury have lower blood ISG15 mRNA expression. The objective of this study is to determine liver damage degree and its influence on blood early pregnancy signaling in beef cattle presenting natural ingestion of Senecio spp. Concentration of GGT, liver damage, progesterone concentrations and ISG15 mRNA expression in polymorphonuclear cells were evaluated on Day 19 following artificial insemination.

\section{MATERIALS AND METHODS}

All chemicals and reagents were purchased from Sigma Chemical Company (Sigma-Aldrich, St. Louis/MO, USA) unless otherwise stated.

Animals and environmental conditions. All experiments were approved by the Animal Ethics Committee (CEUA 5284301018). This study was carried out in Southern Brazil $\left(30^{\circ} 09^{\prime} 18.7^{\prime \prime} \mathrm{S}\right.$ and $\left.55^{\circ} 03^{\prime} 08.6^{\prime \prime} \mathrm{W}\right)$. The presence of plants of genus Senecio spp. are endemic in the area (Karam et al. 2011). Thirty-four Angus cows, aged three to eight years old weighing approximately $450 \mathrm{~kg}$, body condition score from 4 to 6 points, considering a scale from 1 to 9 points (Richards et al. 1986) were included on this study. The cows were kept in native pasture containing high density of Senecio spp., with access to water and mineral salt. All the animals were assessed for uterine status to select only animals without any abnormality on transrectal ultrasonography examination (Aquila PRO - $6.5 \mathrm{MHz}$ linear transducer).

Experimental design. Initially, blood samples were collected from all cows to assess liver damage by serum gamma glutamyl transferase (GGT) 10 days prior to fixed time artificial insemination 
(FTAI). Serum concentration of GGT in all cows ranged from $<1$ to $497 \mathrm{U} / \mathrm{L}$; and $50 \%$ of cows (17 out of 34 ) presented concentrations of GGT below 30U/L. Consequently, we ranked the cows into one of the following experimental groups based on GGT concentration: Group 1 ( $\mathrm{n}=17$, low GGT<30U/L) and Group 2 ( $\mathrm{n}=17$, high GGT $>30 \mathrm{U} / \mathrm{L})$, as indicators of liver injury (Smith 2009). After the initial screening and groups categorized, the cows had their estrous cycle synchronized using the same protocol. The day of FTAI was determined as Day 0. Blood samples were obtained on Day 19 to evaluate ISG15 mRNA on PMNs; serum concentration of progesterone was determined on Day 19. Liver biopsies were collected to verify the presence and degree of liver damage by histological and cytological examination also on Day 19. Pregnancy diagnosis was scanned by ultrasound (Aquila PRO - 6.5 MHz linear transducer) on Day 45 following FTAI.

Synchronization of ovulation and artificial insemination. The animals had their estrous cycle synchronized, starting 10 days prior to FTAI day. The cows received an intravaginal device (IVD) containing 1.9g of progesterone (CIDR, Zoetis, São Paulo, Brazil) and an administration of $2 \mathrm{mg}(\mathrm{im})$ of estradiol benzoate (Sincrodiol, Ourofino, Minas Gerais, Brazil). Two days prior to FTAI (Day -2), IVD was withdrawn and the animals received an injection of $5 \mathrm{mg}(\mathrm{im})$ of dinoprost trometamine (PGF analogue; Lutalyze, Zoetis) and 1mg (im) of estradiol cypionate (ECP; E.C.P. Zoetis). FTAI was performed 48 hours (Day 0) following IVD withdrawal. The semen was obtained from a commercial company, stored in liquid nitrogen and thawed at $37^{\circ} \mathrm{C}$ for 30 seconds for subsequent FTAI. The FTAI was done depositing the semen in the uterine body by the same technician.

Liver biopsy. Liver tissue fragments were collected on Day 19 for histological and cytological examinations to evaluate the presence and the extension of lesions compatible with consumption of Senecio spp. Liver biopsies $(n=8)$ were obtained using a needle inserted into the 11th right intercostal space, approximately $20 \mathrm{~cm}$ below the backline, at the intersection of an imaginary line between the ileum outer tuberosity and the scapula and another line perpendicular to the 11th intercostal space (Barros et al. 2007).

Blood sample collection. Blood samples were collected from the coccygeal vein into $4 \mathrm{~mL}$ tubes containing EDTA and without anticoagulant, using a $21 \mathrm{G}$ needle coupled to a vacuum collection system (BD Vacutainer ${ }^{\circledR}$ ). Samples were collected 10 days before FTAI (Day -10) to evaluate concentration of GGT, and on Day 19 following FTAI to assess progesterone concentration and expression of ISG15 mRNA.

Isolation of polymorphonuclear (PMN) peripheral blood. After blood collection, $2 \mathrm{~mL}$ of whole blood was diluted in $2 \mathrm{~mL}$ of $0.9 \% \mathrm{NaCl}$ and then added on $3 \mathrm{~mL}$ of Ficoll-Paque PREMIUM ${ }^{\circledR}$, and centrifuged at $400 \mathrm{x}$ g for $15 \mathrm{~min}$ room temperature. After centrifugation the fractions obtained were: PBMCs, Ficoll-Paque, PMNs and erythrocytes. All the upper fractions were removed to collect the PMN fraction. Samples were stored in a cryotube at $-80^{\circ} \mathrm{C}$ for subsequent total RNA extraction. After isolation of PMN fraction, a glass-slide fraction-film was prepared to determine the purity of each fraction. Slides were stained using a rapid stain (DiffQuik Differential Stains Set; Fisher Scientific, Waltham/MA, USA) according to the manufacturer's recommendations. The cell fractions purity was accessed based on cell morphology. PMN are classified as neutrophils, eosinophils and basophils. They have condensed, segmented nuclei and are identified by the staining characteristics of their secondary granules. An experienced clinical pathologist examined the slides. A differential cell count was done by identifying 100 consecutive leukocytes using a 100x objective. Samples above $95 \%$ of specific cell type (PMN) were included in this study.
RNA extraction, reverse transcription and real-time PCR. Total RNA was extracted from the PMN cells using Tri Reagent (BD), according to the manufacturer's recommendations. Quantification and estimation of RNA purity was performed using Nanodrop spectrophotometer (Thermo Scientific, Waltham/MA, USA; Absorbance 260/280nm ratio). RNA was treated with DNAse Amplification Grade (Thermo Fisher, Waltham/MA, USA) for 15 minutes at $27^{\circ} \mathrm{C}$ to degrade any DNA molecules. DNAse was inactivated by $1 \mu \mathrm{L}$ of EDTA for 10 minutes at $65^{\circ} \mathrm{C}$. Reverse transcription was performed adding iScript cDNA synthesis Kit (BioRad, Hercules/CA, USA) for 5 minutes at $25^{\circ} \mathrm{C}$ followed by 30 minutes at $42^{\circ} \mathrm{C}$ and 5 minutes at $85^{\circ} \mathrm{C}$. Polymerase chain reaction (qPCR) was conducted in a thermocycler (BioRad, Hercules/ CA, USA) using $2 \mu \mathrm{L}$ of cDNA and $8 \mu \mathrm{L}$ of MIX containing forward and reverse primers (Table 1 ), free nuclease water and GoTaq ${ }^{\circledR}$ Master Mix (Promega Corporation, Madison, USA). Amplification was performed with initial denaturation at $95^{\circ} \mathrm{C}$ for 5 minutes followed by 40 cycles of denaturation at $95^{\circ} \mathrm{C}$ for 15 seconds and annealing/extension at $60^{\circ} \mathrm{C}$ for 30 seconds. To optimize the RT qPCR assay, serial dilutions of cDNA templates were used to generate a standard curve, and efficiency between 90 and $110 \%$ and coefficient of determination (R2) higher than 0.98 were considered. Samples were run in duplicate and the results of all genes were expressed relative to GAPDH and RPS18 reference genes (Pfaffl 2001). Liver evaluation. Analysis of GGT was performed on blood serum samples obtained 10 days prior (Day -10) to FTAI. Serum concentration of GGT was determined by the enzymatic method using Advia 1800 equipment (Siemens). For cytological analysis, slides were prepared with each liver fragment using the imprint technique, air-dried and stained with Diff-Quik ${ }^{\circledR}$ (Diff-Quik ${ }^{\circledR}$ Differential Stain Set, American Scientific Products). Cytological evaluation was based on the typical histological findings associated to pyrrolizidine alkaloid toxicosis (megalocytosis, biliary hyperplasia and fibrosis), as described (Emanuelli etal. 2016). Markedly enlarged hepatocytes (megalocytes) defined megalocytosis; biliary hyperplasia was determined based on the amounts of biliary epithelial cells; fibrosis was determined based on the amounts of fibroblasts. We used a score system for cytology as follows: 0 (absent $0 \%$ ), +1 (mild $<30 \%$ ), +2 (moderate $31 \%-70 \%$ ) and +3 (marked $>70 \%$ ). Samples exhibiting any degree of megalocytosis with or without the other findings were suggestive of seneciosis. For the histological examination, liver fragments were placed into $4 \%$ paraformaldehyde for 24 hours, and processed as follows: ethyl alcohol dehydration, diaphanization in xylene, liquid Paraplastä (Sigma, Brazil), impregnation in a drying stove at $60^{\circ} \mathrm{C}$, and Paraplastä inclusion at room temperature. The Paraplastä blocks containing the tissues were sectioned using a microtome (RM 2335, Leica Biosystems), adjusted for sections of $5 \mu \mathrm{m}$ thickness on glass slides. Afterward, each slide was stained with hematoxylin and eosin (HE). Liver samples were scored considering fibrosis, megalocytosis, biliary duct proliferation and the presence or absence of binucleated cells. Lesions were considered mild $<30 \%$, moderate $30-70 \%$ and severe $>70 \%$.

Table 1. Primers designed for semi quantitative real-time PCR analysis

\begin{tabular}{ccc}
\hline Target & Accession number & \multicolumn{1}{c}{ Primer sequence } \\
\hline ISG15 & NM_174366.1 & F: GGTATCCGAGCTGAAGCAGTT \\
& & R: ACCTCCCTGCTGTCAAGGT \\
GAPDH & NM_001034034.2 & F: GATTGTCAGCAATGCCTCCT \\
& & R: GGTCATAAGTCCCTCCACGA \\
RPS18 & NM_001033614.2 & F: CCTTCCGCGAGGATCCATTG \\
& & R: CGCTCCCAAGATCCAACTAC
\end{tabular}

$\bar{F}=$ Forward, $\mathrm{R}=$ reverse. 
CL diameter and progesterone assay. Corpora lutea diameter (mm) was measured on Day 19 following FTAI through ovarian ultrasonography scanning (Aquila PRO - 6.5 MHz linear transducer). The concentration of progesterone was determined in plasma by chemiluminescent assay kit (ADVIA Centaur, Siemens) on Day 19 following FTAI. The sensitivity of the assay was $0.15 \mathrm{ng} / \mathrm{mL}$ of progesterone.

Statistical analysis. Continuous data were tested for normal distribution using Shapiro-Wilk test and normalized when necessary. Progesterone concentration, GGT and mRNA levels data were analyzed by ANOVA followed by multiple pairwise comparisons (Tukey-Kramer HSD test) and pregnancy rates were analyzed with Chi-square's test using the JMP Software (14; SAS Institute Inc., Cary/NC). Results are presented as mean \pm standard error of the mean (SEM) and $P<0.05$ was considered significant.

\section{RESULTS}

\section{Liver damage}

Firstly, liver damage was classified according to the concentration of serum GGT. The reference concentration of GGT (Smith 2009) has been used to sort into mild (<30U/L) or medium/severe (>31U/L) damage. In our study, serum concentration of GGT data in all cows ranged from $<1$ up to 497 U/L. Fifty percent of cows (17/34) presented concentration of GGT below 30U/L. Consequently, cows from Group $1(\mathrm{n}=17)$ had GGT<30U/L and cows from Group 2 (n=17) had GGT>31U/L. In order to assess liver injury degree induced by Senecio spp., liver biopsies $(\mathrm{n}=8)$ were performed for histological and cytological examination on Day 19 after artificial insemination. The cytology slides were imprinted right after tissue collection. After the examination, four cows had mild megalocytosis $(+1)$ and three had moderate megalocytosis (+2). Increased number of biliary epithelial cells suggesting biliary hyperplasia was noted in six biopsies slides, five scored +1 and one scored +2 . Fibroblasts were not seen in any sample. One sample (1/8) had normal hepatocytes and seven (7/8) samples were suggestive of seneciosis. On the histological slides, all liver samples $(\mathrm{n}=8)$ presented megalocytosis, and the presence of binucleated cells. Samples exhibiting any degree of megalocytosis with or without the other findings were suggestive of seneciosis (Fig.14). Based on cytological and/or histological examinations all
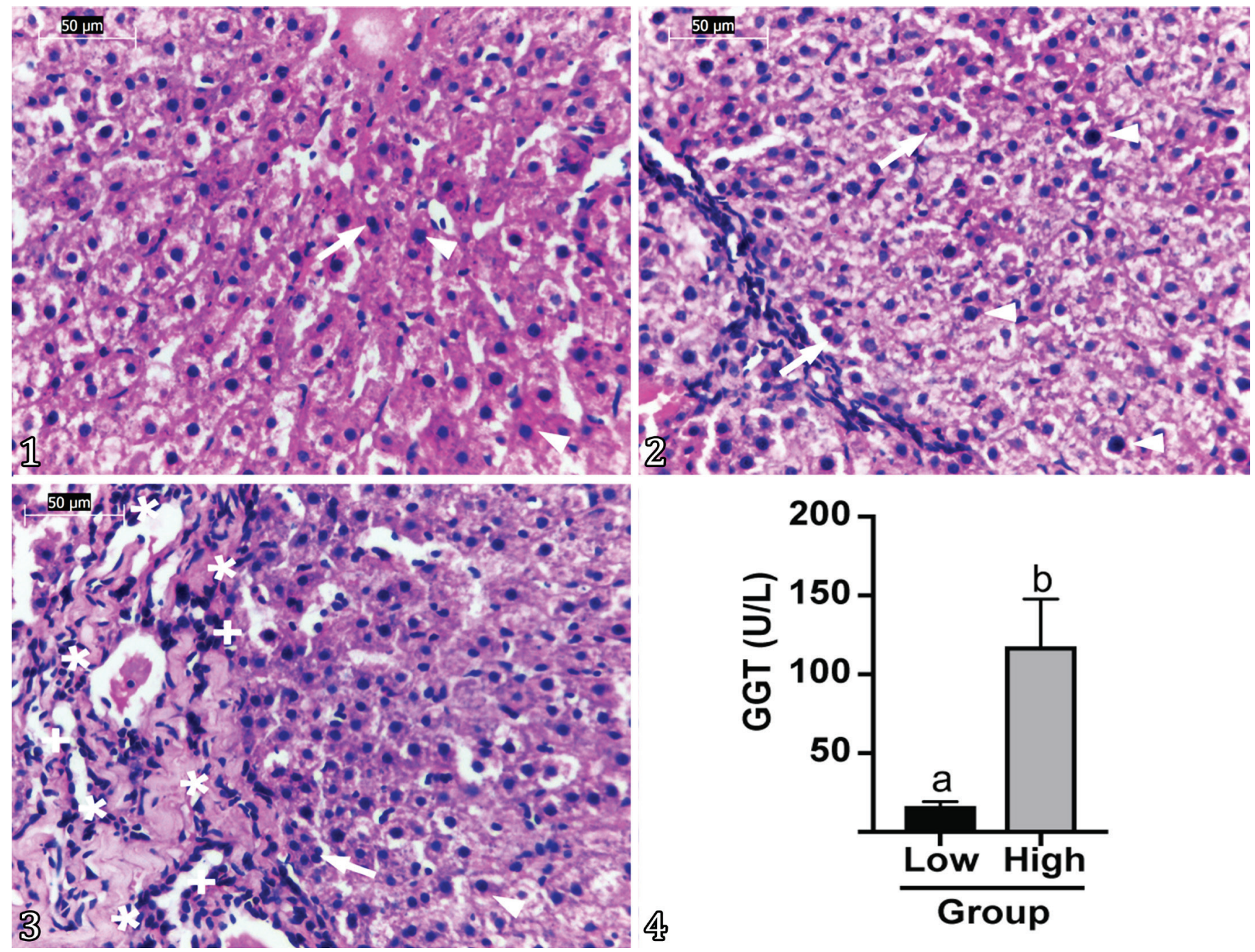

Fig.1-4. Liver histological and serological characterization of seneciosis in beef cattle presenting natural ingestion of Senecio spp. (1,2) Histological section of the liver megalocytosis (arrow head) and binucleated cells (arrow). HE, obj.40x. (3) Fibrosis (asterisk) and proliferative biliary ducts (plus). HE, obj.40x. (4) Serum concentration of GGT (U/L). 
the cows $(\mathrm{n}=8)$ presented findings suggestive of seneciosis. Histological examination is the gold standard to assess liver damage (Barros et al. 2007), however cytological slides have been used as a faster diagnosis method. These findings, together with epidemiological data, indicate exposure to Senecio spp. Also, these results independent of liver damage degree indicate seneciosis in all cows.

Pregnancy status, CL diameter, concentration of progesterone and body condition score

Overall pregnancy rate was $32.35 \%(11 / 34)$. The Group $1(<30$ IU/L) pregnancy rate was $47.06 \%(8 / 17)$ and the Group 2 (GGT>30IU/L) was $17.65 \%(3 / 17)(P<0.05)$. The CL diameter in the cows from Group 1 was greater $(19.82 \mathrm{~mm})$ when compared to cows from the Group $2(15.86 \mathrm{~mm})(P<0.05)$. The concentration of progesterone in the cows from Group 1 was also greater $(11.18 \mathrm{ng} / \mathrm{mL})$ than the concentration in the Group 2 (2.57ng/mL) $(P<0.05)$ (Fig.5-8). When we consider only pregnant cows in both groups, the CL diameter remains grater $(P<0.05)$ in cows from Group 1, however the concentration of progesterone is similar $(P>0.05)$. Body condition score did not differ on all cows from the experiment.

\section{ISG15 mRNA expression on blood PMNs}

Blood samples were collected on Day 19 to address whether maternal recognition of pregnancy signaling would be affected by seneciosis. PMNs were isolated and ISG15 mRNA evaluated after FTAI. The expression of ISG15 mRNA in blood PMNs did not differ between non-pregnant and pregnant cows on Day 19 (NP $=0.62 \pm$ SEM vs P0.97 \pm SEM; $P>0.05$ ) following FTAI. When sorted by group, Group 1 (GGT<30IU/L; NP=0.71 vs $P=1.25$ ) and Group 2 (GGT>31IU/L; NP=0.62 vs $P=0.88$ ) presented no difference on Day19 ISG15 mRNA expression $(P>0.05)$ (Fig.5-8). Also, ISG15 mRNA expression had no correlation with pregnancy status, CL diameter or concentration of progesterone.
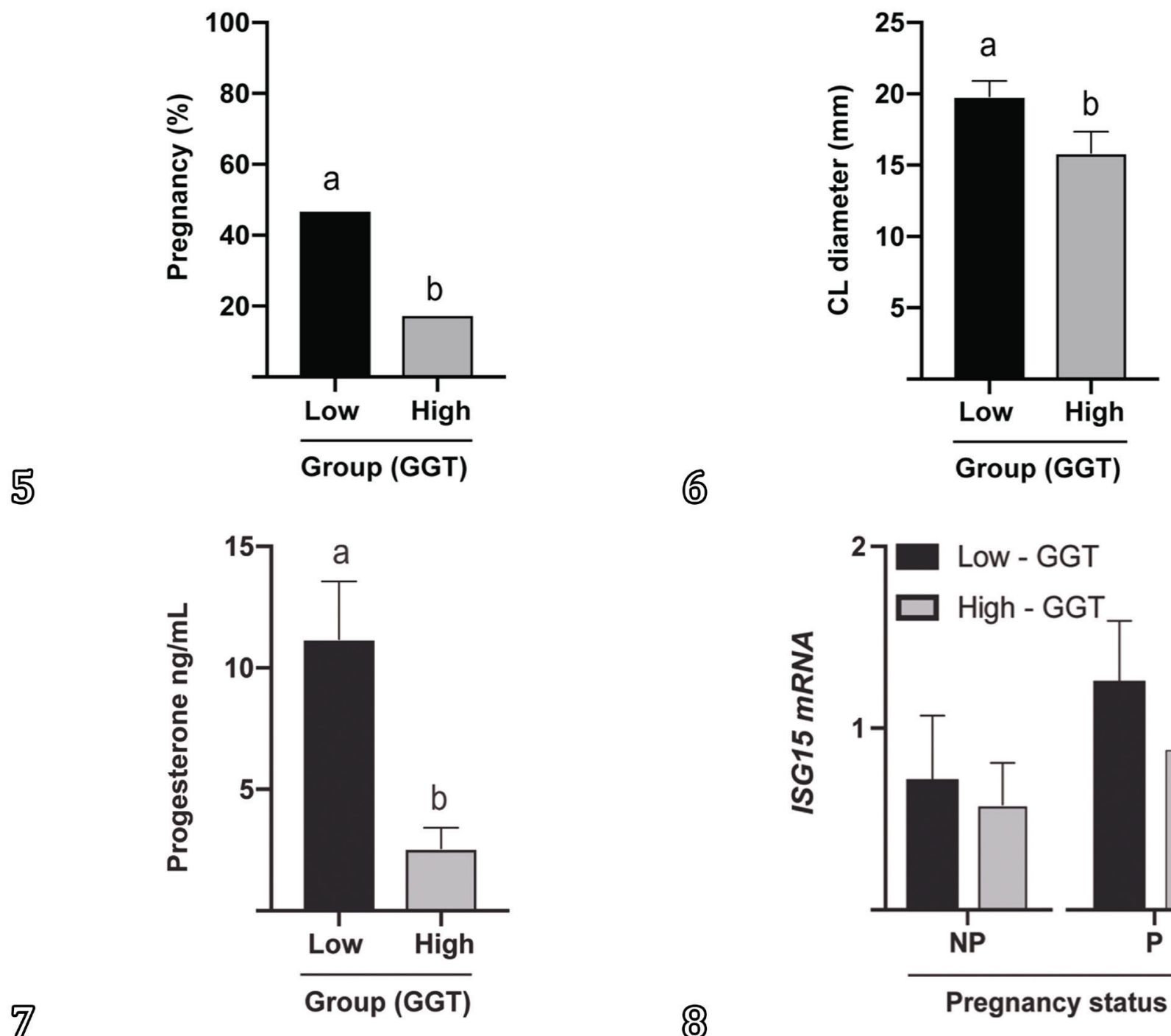

(6)

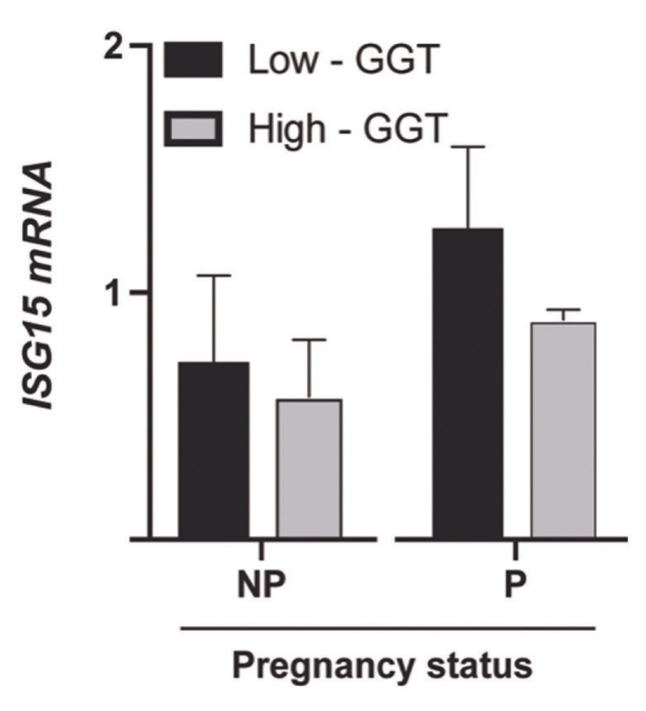

Fig.5-8. Reproductive status of beef cows presenting seneciosis classified by serum concentration of GGT. (5) Pregnancy rate, (6) corpora lutea diameter, (7) serum concentration of progesterone in low $(<30 \mathrm{U} / \mathrm{L})$ and high (>30U/L) GGT cows. (8) ISG15 mRNA relative expression in low $(<30 \mathrm{U} / \mathrm{L})$ and high $(>30 \mathrm{U} / \mathrm{L})$ GGT cows according to pregnancy status. Different letters represent difference. $P<0.05$. 


\section{DISCUSSION}

Senecio spp. consumption leads to pyrrolizidine alkaloids (PA) ingestion, which are natural phytotoxins (Elias et al. 2011), and cause irreversible damage to the liver, impairing liver function (Cheeke 1988). GGT evaluation is indicated for the diagnosis of cholestasis in ruminants, as it is an enzyme associated with cell membranes of the bile ducts and channels (Santos et al. 2008). It is considered the best biochemical marker for the diagnosis of Senecio spp. toxicity, due to unremarkable changes in all other hematological and biochemical parameters (Giaretta et al. 2014). For this reason, we used a limit of GGT concentration to categorize the cows in the present study into two groups, as the blood concentration of GGT is an indicative of liver damage, subsequently confirmed by cytological and histological analyses. The use of cytology as a fast-diagnostic method (Emanuelli et al. 2016) and the histology as the gold standard (Barros et al. 2007) to diagnose Senecio spp. poisoning confirmed the detection of seneciosis in all the cows in the present study.

The liver is considered the main organ in the metabolism and distribution of nutrients (Kozloski 2011) and it is responsible for cholesterol synthesis and progesterone clearance (Wiltbank et al. 2014). Some disorders, as fatty liver syndrome, also interfere with reproductive performance in dairy cows (Bertoni et al. 2008). In the present study, beef cows diagnosed with seneciosis have their reproductive performance reduced. In the Group $1(\mathrm{GGT}<30 \mathrm{U} / \mathrm{dL})$, the pregnancy rate was about $50 \%$, whilst in Group 2 (GGT $>30 \mathrm{U} / \mathrm{dL})$, the pregnancy rate was bellow $20 \%$.

In the present study CL diameter and concentration of progesterone were lower in Group 2. There are some controversy regarding to CL size and progesterone synthesis. Historically, the CL diameter is directly related to serum concentration of progesterone (Assey et al. 1993); however, a recent study reveals the concentration of progesterone is related to CL size early in the cycle, but not in mid-late-cycle (Mann 2009). Also, indirect effects on embryo survival due to the lower availability of nutrients released in general circulation or directly by interference with progesterone synthesis may impair the CL development and progesterone concentration. Cholesterol on low- or high-density lipoprotein forms is the precursor for progesterone biosynthesis (Niswender et al. 2000). Greater concentrations of cholesterol are related to steroidogenic enhancing capacity of first-wave dominant follicles, the diameter of dominant follicles in early postpartum, and increasing estradiol levels during the first follicular wave resulting in a shorter anovulatory interval (Butler et al. 1996). The increase in circulating progesterone concentrations in the postovulatory period promotes an increase in pregnancy rate (Forde et al. 2009). Progesterone production is regulated by the development of the corpus luteum after the LH peak, the number of granulosa cells that luteinize into large luteal cells and the constitutive progesterone production by the large luteal cells (Bogan \& Niswender 2007). Furthermore, circulating progesterone concentration is determined by the balance between luteal production and its hepatic metabolism, which is determined by blood flow (Nelson \& Cox 2012, Wiltbank et al. 2014). Seneciosis promotes liver disease by accumulation of pyrolizidinic alkaloids in the liver, and the main finding is hepatic megalocytosis (Barros et al. 2007); and interestingly, the same lesion was described in large luteal cells
(Krabbe et al. 2015). This may influence the smaller CL and lower concentration on progesterone in cows with elevated concentrations of GGT. When considering only pregnant cows from both Groups 1 and 2, the CL diameter remains greater on Group 1 and concentration of progesterone are similar. This means the greater concentration of blood progesterone is consequence of poor liver clearance due to seneciosis, instead of luteal production, since increase of blood flow increase metabolic clearance of steroids in healthy cows (Sangsritavong et al. 2002)

IFNT is produced by the conceptus trophoblastic cells in early pregnancy and acts on the endometrium abrogating estrogen and oxytocin receptor gene expression, to prevent luteolytic pulses of PGF (Spencer \& Bazer 1996). Additionally, IFNT leaves the uterus through uterine vein increasing the expression of various interferon-stimulated genes (ISGs) in the uterus, corpus luteum, and blood cells (Oliveira et al. 2007, Bott et al. 2010). Adequate progesterone concentrations are essential in the post-conception period to stimulate conceptus elongation, to increase IFNT production (Brooks \& Spencer 2015), and to improve pregnancy rates (Carter et al. 2008). After the description of interferon tau endocrine action (Oliveira et al. 2007), several studies have described the expression of ISG in the blood and possible its use as a pregnancy marker (Han et al. 2006, Kizaki et al. 2013, Haq et al. 2016). However, some studies have proposed to use the expression of ISGs in neutrophils can be peripheral markers to predict embryonic mortality (Sheikh et al. 2018). In our study, no difference in ISG15 mRNA expression was observed on Day 19 following FTAI when comparing pregnancy status and concentration of GGT (Groups 1 and 2), and their interaction. It's known that during early pregnancy in sheep there is ISG15 mRNA expression increase only in pregnant ewes (Romero et al. 2015). The pattern of ISG15 expression in late embryonic mortality is similar to pregnant cows, which are different from conception failure and early embryonic mortality. Interferon tau-stimulated gene expression in neutrophils may act as a biomarker to predict conception failure and embryonic mortality in dairy cows (Sheikh et al. 2018). This is interpreted to mean, initially the majority of cows became pregnant (IFNT signal) together with open cows and early embryonic mortality (no IFNT signal) regardless of their hepatic damage. All the pregnant cows signal the pregnancy, however the cows presenting concentration of GGT above 31IU/L, had a liver and luteal involvement caused by Senecio spp. poisoning, leading to a decrease in CL volume and consequently late embryonic mortality. The cow presenting the greatest concentration of GGT (497U/L) in our study presented a large CL $(22 \mathrm{~mm})$ and high ISG15 mRNA relative expression on Day 19, however low concentration of progesterone (1.17ng/ $\mathrm{mL}$ ), and it was not pregnant on Day 45 US scanning; this suggests embryo mortality, probably beyond D19. According to (Han et al. 2006) this phenomenon may indicate that cows are in the process of embryonic mortality perhaps related to corpus luteum insufficiency, changes in endometrial release and cellular response to IFNT.

\section{CONCLUSIONS}

Serum concentrations of gamma glutamyl transferase (GGT) indicated liver damage, confirmed by cytological and histological examinations, which was compatible with seneciosis. 
Reducing hepatic function compromises corpus luteum (CL) diameter, probably the availability of nutrients necessary to embryonic survival and the recognition of pregnancy.

Liver injury and/or concentration of GGT does not alter ISG15 expression on blood neutrophils, however cows presenting lower concentration of GGT ( $<30 \mathrm{U} / \mathrm{L})$ had increased pregnancy status. The different intensities of hepatic damage impact embryonic development prior to weight loss and decline in body condition score, suggesting serum concentration of GGT may be an indicator before breeding season. Therefore, the concentration of GGT allow us to screen liver status and foresee a successful pregnancy in beef cattle.

Acknowledgements.- The authors thank to "Campo de Instrução Barão de São Borja" - EB for providing the animals for the study. This study was supported by "Coordenação de Aperfeiçoamento de Pessoal de Nível Superior" (CAPES, Financial code 001), “Fundação de Amparo à Pesquisa do Estado do Rio Grande do Sul” (FAPERGS), and "Conselho Nacional de Desenvolvimento Científico e Tecnológico" (CNPq).

Conflict of interest statement.- The authors have no competing interests.

\section{REFERENCES}

Antoniazzi A.Q., Webb B.T., Romero J.J., Ashley R.L., Smirnova N.P., Henkes L.E., Bott R.C., Oliveira J.F., Niswender G.D., Bazer F.W. \& Hansen T.R. 2013. Endocrine delivery of interferon tau protects the corpus luteum from prostaglandin F2 alpha-induced luteolysis in ewes. Biol. Reprod. 88(6):144. <https://dx.doi.org/10.1095/biolreprod.112.105684><PMid:23616594>

Assey R.J., Purwantara B., Greve T., Hyttel P. \& Schmidt M.H. 1993. Corpus luteum size and plasma progesterone levels in cattle after cloprostenolinduced luteolysis. Theriogenology 39(6):1321-1330. <https://dx.doi. org/10.1016/0093-691X(93)90234-V>

Austin K.J., Ward S.K., Teixeira M.G., Dean V.C., Moore D.W. \& Hansen T.R. 1996. Ubiquitin cross-reactive protein is released by the bovine uterus in response to interferon during early pregnancy. Biol. Reprod. 54(3):600606. <https://dx.doi.org/10.1095/biolreprod54.3.600><PMid:8835381>

Barros C.S.L., Castilhos L.M.L., Rissi D.R., Kommers G.D. \& Rech R.R. 2007. Biópsia hepática no diagnóstico da intoxicação por Senecio brasiliensis (Asteraceae) em bovinos. Pesq. Vet. Bras. 27(1):53-60. <https://dx.doi. org/10.1590/S0100-736X2007000100010>

Basile J.R., Ferraz Diniz J.M., Okano W., Cirio S.M. \& Leite L.C. 2005. Intoxicação por Senecio spp. (Compositae) em bovinos no sul do Brasil. Acta Scient. Vet. 33(1):63-68. <https://dx.doi.org/10.22456/1679-9216.14565>

Bertoni G., Trevisi E., Han X. \& Bionaz M. 2008. Effects of inflammatory conditions on liver activity in puerperium period and consequences for performance in dairy cows. J. Dairy Sci. 91(9):3300-3310. <https://dx.doi. org/10.3168/jds.2008-0995><PMid:18765589>

Bogan R.L. \& Niswender G.D. 2007. Constitutive steroidogenesis in ovine large luteal cells may be mediated by tonically active protein kinase A. Biol. Reprod. 77(2):209-216. <https://dx.doi.org/10.1095/biolreprod.106.059618> $<$ PMid:17409373>

Bott R.C., Ashley R.L., Henkes L.E., Antoniazzi A.Q., Bruemmer J.E., Niswender G.D., Bazer F.W., Spencer T.E., Smirnova N.P., Anthony R.V. \& Hansen T.R. 2010. Uterine vein infusion of interferon tau (IFNT) extends luteal life span in ewes. Biol. Reprod. 82(4):725-735. <https://dx.doi.org/10.1095/ biolreprod.109.079467><PMid:20042537>

Brooks K. \& Spencer T.E. 2015. Biological roles of interferon tau (IFNT) and type I IFN receptors in elongation of the ovine conceptus. Biol. Reprod. 92(2):47. <https://dx.doi.org/10.1095/biolreprod.114.124156><PMid:25505203>
Butler W.R., Calaman J.J. \& Beam S.W. 1996. Plasma and milk urea nitrogen in relation to pregnancy rate in lactating dairy cattle. J. Anim. Sci. 74(4):858865. <https://dx.doi.org/10.2527/1996.744858x><PMid:8728008>

Carter F., Forde N., Duffy P., Wade M., Fair T., Crowe M.A., Evans A.C.O., Kenny D.A., Roche J.F. \& Lonergan P. 2008. Effect of increasing progesterone concentration from Day 3 of pregnancy on subsequent embryo survival and development in beef heifers. Reprod. Fertil. Develop. 20(3):368-375. <https://dx.doi.org/10.1071/RD07204><PMid:18402756>

Cheeke P.R. 1988. Toxicity and metabolism of pyrrolizidine alkaloids. J. Anim. Sci. 66(9):2343-2350. <https://dx.doi.org/10.2527/jas1988.6692343x> $<$ PMid:3049495>

Elias F., Latorre A., Pípole F., Haraguchi M., Górniak S. \& Hueza I. 2011 Haematological and immunological effects of repeated dose exposure of rats to integerrimine N-oxide from Senecio brasiliensis. Food Chem. Toxol. 49(9):2313-2319. <https://dx.doi.org/10.1016/j.fct.2011.06.032>

Emanuelli M.P., Antoniazzi A.Q., Cecim M.S. \& Fighera R.A. 2016. What is your diagnosis? Liver from a cow. Vet. Clin. Pathol. 45(4):721-722. <https:// dx.doi.org/10.1111/vcp.12414><PMid:27787899>

Farin E.C., Imakawa K. \& M Roberts R. 1989. In situ localization of mRNA for the interferon, ovine trophoblast protein1, during early embryonic development of the sheep. Mol. Endocrinol. 3(7):1099-1107. <https:// dx.doi.org/10.1210/mend-3-7-1099>

Forde N., Carter F., Fair T., Crowe M.A., Evans A.C.O., Spencer T.E., Bazer F.W., Mcbride R., Boland M.P., O'gaora P., Lonergan P. \& Roche J.F. 2009. Progesterone-regulated changes in endometrial gene expression contribute to advanced conceptus development in cattle. Biol. Reprod. 81(4):784-794. <https://dx.doi.org/10.1095/biolreprod.108.074336><PMid:19553605>

Giaretta P.R., Panziera W., Galiza G.J.A., Brum J.S., Bianchi R.M., Hammerschmitt M.E., Bazzi T. \& Barros C.S.L. 2014. Seneciosis in cattle associated with photosensitization. Pesq. Vet. Bras. 34(5):427-432. <https://dx.doi. org/10.1590/S0100-736X2014000500007>

Han H., Austin K.J., Rempel L.A. \& Hansen T.R. 2006. Low blood ISG15 mRNA and progesterone levels are predictive of non-pregnant dairy cows. J. Endocrinol. 191(2):505-512.<https://dx.doi.org/10.1677/joe.1.07015> $<$ PMid:17088421>

Haq I.U., Han Y., Ali T., Wang Y., Gao H., Lin L., Wu Y., Wu S. \& Zeng S. 2016. Expression of interferon-stimulated gene ISG15 and ubiquitination enzymes is upregulated in peripheral blood monocyte during early pregnancy in dairy cattle. Reprod. Biol. 16(4):255-260. <https://dx.doi.org/10.1016/j. repbio.2016.10.001><PMid:27802914>

Imakawa K., Anthony R.V., Kazemi M., Marotti K.R., Polites H.G. \& Roberts R.M. 1987. Interferon-like sequence of ovine trophoblast protein secreted by embryonic trophectoderm. Nature 330(6146):377-379. <https://dx.doi. org/10.1038/330377a0 > <PMid:2446135>

Karam F.C., Schild A.L. \& Mello J.R.B.D. 2011. Intoxicação por Senecio spp. em bovinos no Rio Grande do Sul: condições ambientais favoráveis e medidas de controle. Pesq. Vet. Bras. 31(7):603-609. <https://dx.doi.org/10.1590/ S0100-736X2011000700010>

Karam F.S.C., Soares M.P., Haraguchi M., Riet-Correa F., Méndez M.D.C. \& Jarenkow J.A. 2004. Aspectos epidemiológicos da seneciose na região sul do Rio Grande do Sul. Pesq. Vet. Bras. 24(4):191-198. <https://dx.doi. org/10.1590/S0100-736X2004000400004>

Kizaki K., Shichijo-Kizaki A., Furusawa T., Takahashi T., Hosoe M. \& Hashizume K. 2013. Differential neutrophil gene expression in early bovine pregnancy. Reprod. Biol. Endocrinol. 11:6. <https://dx.doi.org/10.1186/1477-782711-6><PMid:23384108>

Kozloski G.V. 2011. Bioquimica dos Ruminantes. 3rd ed. Editora UFSM, Santa Maria, p.105-169.

Krabbe A.A., Gonçalves M.A., Pozzobon R., Pessoa R.M.C., Soares M.P., Costa R.A. \& Anjos B.L. 2015. Megalocitose de células luteínicas grandes de vacas 
prenhes com seneciose. Pesq. Vet. Bras. 35(1):33-38. <https://dx.doi. org/10.1590/S0100-736X2015000100008>

Mann G.E. 2009. Corpus luteum size and plasma progesterone concentration in cows. Anim. Reprod. Sci. 115(1/4):296-299. <https://dx.doi.org/10.1016/j. anireprosci.2008.11.006>

Nelson D.L. \& Cox M.M. 2012. Lipid Biosynthesis, p.811-853. In: Ibid. (Eds), Lehninger Principles of Biochemistry. $6^{\underline{a}}$ ed. W.H. Freeman, United States.

Niswender G.D., Juengel J.L., Silva P.J., Rollyson M.K. \& McIntush E.W. 2000. Mechanisms controlling the function and life span of the corpus luteum. Physiol. Rev. 80(1):1-29. <https://dx.doi.org/10.1152/physrev.2000.80.1.1> <PMid:10617764>

Oliveira J.F., Henkes L.E., Ashley R.L., Purcell S.H., Smirnova N.P., Veeramachaneni D.R., Anthony R.V. \& Hansen T.R. 2007. Expression of interferon (IFN)stimulated genes in extrauterine tissues during early pregnancy in sheep is the consequence of endocrine IFN- $\tau$ release from the uterine vein. Endocrinology 149(3):1252-1259. <https://dx.doi.org/10.1210/en.20070863> <PMid:18063687>

Pfaffl M.W.2001. A new mathematical model for relative quantification in realtime RT-PCR. Nucleic Acids Res. 29(9):e45. <https://dx.doi.org/10.1093/ nar/29.9.e45><PMid:11328886>

Richards M.W., Spitzer J.C. \& Warner M.B. 1986. Effect of varying levels of postpartum nutrition and body condition at calving on subsequent reproductive performance in beef cattle. J. Anim. Sci. 62(2):300-306. <https://dx.doi.org/10.2527/jas1986.622300x>

Romero J.J., Antoniazzi A.Q., Nett T.M., Ashley R.L., Webb B.T., Smirnova N.P., Bott R.C., Bruemmer J.E., Bazer F.W. \& Anthony R.V. 2015. Temporal release, paracrine and endocrine actions of ovine conceptus-derived interferontau during early pregnancy. Biol. Reprod. 93(6):146. <https://dx.doi. org/10.1095/biolreprod.115.132860 > <PMid:26559679>

Sangsritavong S., Combs D.K., Sartori R., Armentano L.E. \& Wiltbank M.C. 2002. High feed intake increases liver blood flow and metabolism of progesterone and estradiol-17beta in dairy cattle. J. Dairy Sci. 85(11):2831-2842. <https:// dx.doi.org/10.3168/jds.S0022-0302(02)74370-1><PMid:12487450>

Santos J.C.A., Riet-Correa F., Simões S.V.D. \& Barros C.S.L. 2008. Patogênese, sinais clínicos e patologia das doenças causadas por plantas hepatotóxicas em ruminantes e eqüinos no Brasil. Pesq. Vet. Bras. 28(1):1-14. <https:// dx.doi.org/10.1590/S0100-736X2008000100001>
Sheikh A.A., Hooda O.K., Kalyan A., Kamboj A., Mohammed S., Alhussien M., Reddi S., Shimray P.G., Rautela A., Pandita S., Kapila S., De S. \& Dang A.K. 2018. Interferon-tau stimulated gene expression: a proxy to predict embryonic mortality in dairy cows. Theriogenology 120:61-67.<https:// dx.doi.org/10.1016/j.theriogenology.2018.07.028>

Smith B.P. 2009. Diseases of the alimentary tract, p.739-873. In: Ibid. (Eds), Large Animal Internal Medicine. $5^{\underline{a}}$ ed. Elsevier Mosby, Missouri.

Spencer T.E. \& Bazer F.W. 1996. Ovine interferon tau suppresses transcription of the estrogen receptor and oxytocin receptor genes in the ovine endometrium. Endocrinology 137(3):1144-1147. <https://dx.doi. org/10.1210/endo.137.3.8603586 > <Mid:8603586>

Spencer T.E. \& Bazer F.W. 2004. Conceptus signals for establishment and maintenance of pregnancy. Reprod. Biol. Endocrin. 2:49. <https://dx.doi. org/10.1186/1477-7827-2-49><PMid:15236653>

Spencer T.E., Forde N. \& Lonergan P. 2016. The role of progesterone and conceptus-derived factors in uterine biology during early pregnancy in ruminants. J. Dairy Sci. 99(7):5941-5950. <https://dx.doi.org/10.3168/ jds.2015-10070> <PMid:26387021>

Spencer T.E., Johnson G.A., Bazer F.W., Burghardt R.C. \& Palmarini M. 2006. Pregnancy recognition and conceptus implantation in domestic ruminants: roles of progesterone, interferons and endogenous retroviruses. Reprod. Fertil. Develop. 19(1):65-78. <https://dx.doi.org/10.1071/RD06102> <PMid:17389136>

Toji N., Shigeno S., Kizaki K., Koshi K., Matsuda H., Hashiyada Y., Imai K., Takahashi T., Ishiguro-Oonuma T. \& Hashizume K. 2017. Evaluation of interferon-stimulated genes in peripheral blood granulocytes as sensitive responders to bovine early conceptus signals. Vet. J. 229:37-44. <https:// dx.doi.org/10.1016/j.tvjl.2017.10.007> <PMid:29183572>

Wiltbank M., Baez G., Garcia-Guerra A., Toledo M., Monteiro P., Melo L., Ochoa J., Santos J. \& Sartori R. 2016. Pivotal periods for pregnancy loss during the first trimester of gestation in lactating dairy cows. Theriogenology 86(1):239-253. <https://dx.doi.org/10.1016/j.theriogenology.2016.04.037> $<$ PMid:27238438>

Wiltbank M.C., Souza A.H., Carvalho P.D., Cunha A.P., Giordano J.O., Fricke P.M., Baez G.M. \& Diskin M.G. 2014. Physiological and practical effects of progesterone on reproduction in dairy cattle. Animal 8(Supl.1):70-81. <https://dx.doi.org/10.1017/S1751731114000585><PMid:24703103> 